\title{
ИСПОЛЬЗОВАНИЕ ЗАЩИТНЫХ НЕЙРОФИЗИОЛОГИЧЕСКИХ РЕАКЦИЙ ГОЛОВНОГО МОЗГА ПРИ ФОРМИРОВАНИИ ПРЕВЕНТИВНОЙ ЩИШЕМИЧЕСКОЙ ТОЛЕРАНТНОСТИ" (ПРЕ- И ПОСТКОНДИЦИОНИРОВАНИЕ) В ЦЕЛЯХ ЛЕЧЕНИЯ И РЕАБИЛИТАЦИИ БОЛЬНЫХ С ПОСТИНСУЛЬТНЫМИ ПСИХОПАТОЛОГИЧЕСКИМИ РАССТРОЙСТВАМИ
}

\author{
๑К. В. Шевченко-Битенский, В. С. Битенский

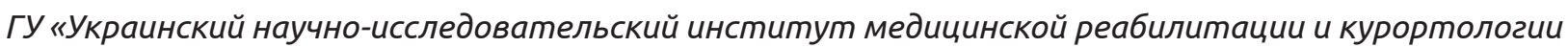 \\ МОЗ Украины",, Одесса
}

РЕЗЮМЕ. По данным ВОЗ, от инсульта ежегодно страдают более 1 млн человек. Чаще всего встречаются ишемические инсульты (87\%), реже - геморрагические (10\%) или инсульты с кровоизлияниями в субарахноидальное пространство (3\%).

Феномен «ишемической толерантности» был введен K. Kitagawa в 1990 г. при описании защитного эффекта малых доз церебральных гипертермий $\left(+35^{\circ} \mathrm{C}\right)$ от действия значительно более выраженных раздражителей. Впервые подобный эффект был предсказан С. П. Боткиным (1867), применен при гипоксии миокарда С. М. Мuггу et al. в 1986 г.; он получил название «пре- и посткондиционирование».

Цель - исследовать терапевтическую эффективность применения так называемой «ишемической толерантности" у 48 больных с различной психопатологической симптоматикой, возникающей после перенесенного инсульта.

Материал и методы. Было проведено исследование 48 больных мужчин с постинсультными психическими расстройствами в виде различной психопатологической симптоматики.

Выводы. Применение слабой краниоцеребральной гипо- и гипертермии $\left(35^{\circ} \mathrm{C}-37,5^{\circ} \mathrm{C}\right)$ создавало в ткани мозга эффект «ишемической толерантности» и, вместе с ингаляцией ксенона и введением нейропротекторов церебролизина (10,0 мг) и вальпроата (400-800 мг), привело к практическому исчезновению постинсультной психопатологической симптоматики.

КЛЮЧЕВЫЕ СЛОВА: постинсультная психопатологическая симптоматика; «ишемическая толерантность»; пре- и посткондиционирование; гипо- и гипертермия.

$$
\begin{array}{r}
\text { «Что нас не убивает, делает нас сильнее» } \\
\text { Ф. Ницше (1844-1900 гг.) } \\
\text { «Тлько доза делает яд ядом» } \\
\text { Парацельс (1493-1541 гг.) }
\end{array}
$$

Вступление. По данным ВОЗ, ежегодно от инсульта страдают более 1 млн человек. Чаще других (87 \%) встречаются инсульты ишемические, в $10 \%$ - геморрагические; в 3 \% - инсульты с кровоизлияниями в субарахноидальное пространство [1]. Практически все инсультные поражения сопровождаются не только когнитивными расстройствами, вплоть до деменции, но и психопатологической симптоматикой, проявляющейся невротическими реакциями, неврозами, интрапсихическими расстройствами в виде иллюзий, галлюцинаций, бредовых идей, эффекторными нарушениями, расстройствами личности и прочее. Применение в целях лечения и реабилитации большого арсенала психотропных средств, включающих, в основном, нейролептики, приводит к хронизированию и усугублению тяжести постинсультного расстройства.

Психофармакологи всего мира сегодня создают множество субстанций и лекарственных препаратов нейропротективного действия, но до настоящего времени ни один из исследованных лекарственных препаратов с доказанной в эксперименте нейропротективной активностью не получил широкого применения в клинической практике [2-5]. Чаще всего гематоэнцефалический барьер человеческого мозга не «пропускает" эти крупномолекулярные соединения. Именно в силу крайне малой эффективности фармакологических нейротропных воздействий сегодня наиболее перспективно использование внутренних, генетически детерминированных защитных механизмов головного мозга.

В последние годы $[6,7]$ стало известно, что создание одного или нескольких эпизодов ишемии малой интенсивности, создаваемой с помощью легкой гипертермии, приводит к защитному эффекту от действия повреждающих факторов гораздо большей активности. Этот феномен был назван K. Kitagawa «ишемической толерантностью» и был почти дословно предсказан С. П. Боткиным (1867), а также законами Пфлюгера (1859), Арндта-Шульца (1883), теорией гормезиса (1943). Затем расширен и теоретически обоснован в ис- 
Огляди літератури, оригінальні дослідження, погляд на проблему, ювілеї

следованиях П. В. Симонова (1962), Г. Селье (1936-1950-1982), Л. И. Гаркави (1979). Позднее, всего лишь через 10 лет, R. Laure et al. (1984) установил значимость слабых эпизодов ишемии миокарда для создания «ишемической толерантности», то есть устойчивости сердечной мышцы к ишемии, а [8] объяснил защитный эффект ишемической индукции эффектами нейропротекции, назвав их пре- или посткондиционированием. Очевидно, мозговое пре- и посткондиционирование и «ишемическая толерантность» ткани головного мозга представляют собой один и тот же нейрофизиологический феномен.
Несмотря на колоссальное количество экспериментальных работ, подтверждающих эффективность повышения «ишемической толерантности», этот феномен практически не используется в клинической нейрофизиологии.

Для изучения эффективности феномена «ишемической толерантности" при постинсультных расстройствах нами было исследовано 48 больных мужчин, перенесших инсульты, осложненные психопатологической симптоматикой (табл. 1), в возрасте от 42 до 73 лет (спустя 1 день - 1 неделю после мозговой катастрофы).

Таблица 1. Структура психопатологической симптоматики у обследованных больных

\begin{tabular}{|l|c|c|c|c|c|}
\hline $\begin{array}{c}\text { Основные психопатологические } \\
\text { симптомы и синдромы }\end{array}$ & $\begin{array}{c}\text { К-во больных } \\
\text { до лечения }\end{array}$ & $\%$ & $\begin{array}{c}\text { К-во больных } \\
\text { после лечения }\end{array}$ & $\%$ \\
\hline Аффективный (тревога, депрессия) & 46 & 98 & 8 & 17 & 0,001 \\
\hline Деперсонализация -дереализация & 8 & 18 & 1 & 3 & 0,001 \\
\hline Невротические & 24 & 52 & 6 & 14 & 0,001 \\
\hline Растерянность & 46 & 100 & 3 & 7 & 0,001 \\
\hline Галлюцинаторно-бредовый & 32 & 69,5 & 1 & 3 & 0,001 \\
\hline Помрачение сознания & 22 & 48 & 1 & 3 & 0,001 \\
\hline Эпилептиформный & 13 & 28 & - & - & 0,001 \\
\hline Психоорганический & 16 & 34 & 3 & 6 & 0,001 \\
\hline Психомоторное возбуждение \\
$\begin{array}{l}\text { хаотическое } \\
\text { целеноправленное }\end{array}$ & 34 & 74 & - & - & 0,001 \\
\cline { 2 - 6 } & 30 & 65 & - & - & 0,001 \\
\hline Астенический & 4 & 9 & - & - & 0,001 \\
\hline Истерическая стигматизация & 18 & 100 & 30 & 65 & 0,01 \\
\hline
\end{tabular}

Для экспериментально-психологического исследования использовались: Краткая шкала психического состояния (MMIE) (M. F. Folstein et al); Квантифицированная шкала оценки клинико-фармакологического действия лечебных факторов (А. В. Вальдман, Ю. А. Александровский, 1987); Стандартизованный мультифакторный метод исследования личности (СМИЛ, адаптация ММРI Собчак Л. Н.), Клиническая рейтинговая шкала деменции (CZR, Morris I. C.), последняя применялась после прекращения психотических расстройств; PDAS (Psychiatric Disabiliti Assesment (Beck A., Weissman A., 1988). Тестирование осуществлялось с помощью программного устройства «КПД», реализующего компьютерную психологическую диагностику и статистическую отработку результатов.

В качестве агентов, создающих «ишемическую толерантность» мозговой ткани, применялись краниоцеребральная гипо- и гипертермия, создаваемая элементами Пельтье, расположенными по своду черепа по международной cxeme Yung I. (1953), (регистрационный № заявки u201807944). Преимущество этой схемы наложения электродов Пельтье при гипо- и гипертермии в том, что они свободно и равномерно охватыва- ют поверхность мозга. Применение элементов Пельтье обеспечивает снижение температуры до $+35^{\circ}$ и повышение до $+38^{\circ}$ (температура измеряется датчиками, расположенными в слуховом проходе и в подмышечной впадине). Смена церебральной гипотермии на гипертермию происходит в течение 10-15 мин, всего 10-12 раз за процедуру. Экспозиция всей процедуры - до 1,52 часов. Каждую процедуру проводят только после кислородно-ксеноновой ингаляции (70\% $\mathrm{O}_{2}$ 30 \% Хе). Используется до 7-8 л ксенона на одну ингаляцию. Ксенон в этом случае оказывал эффект пре- и посткондиционирования [9]. Повышая проходимость гематоэнцефалического барьера, Хе также служит адъювантом (энхансером) для сопровождения в ткань мозга вводимых внутривенно растворов вальпроата натрия (400800 мг) и церебролизина 10,0 мг.

Выводы. Курс реабилитационной терапии описанным комплексом составляет от 14 до 28 дней и статистически достоверно приводит к практическому исчезновению основной постинсультной психопатологической симптоматики, как по клиническим данным, так и по экспериментально-психологическим исследованиям. 
Огляди літератури, оригінальні дослідження, погляд на проблему, ювілеї ЛИТЕРАТУРА

1. Stroke / Y. A. Donnan, M. Fisher, M. Macleod, S. M. Davis // Lancet. - 2008. - Vol. 371. - P. 1612-1623.

2. A systematic review of the effectiveness, coss-effectiveness and barriers to implementation of thrombolytic and neuroprotective therapy for acute ischaemic stroke in the NHS / P. Sandercock, E. Berge, M. Dennis // Health Technol. Assess. - 2002. - Vol. 6 (26). - P. 1-112.

3. Up-regulation of endothelial nitric oxide synthase via phosphatidylinositol 3-kinase pathway contributes to ischemic tolerance in the CAl subfield of gerbil hippocampus / A. Hashiguchi, S. Yano, M. Morioka [et al.] // J. Ceber. Blood Flow Metab. - 2004. - Vol. 24 (3). - P. 271-279.

4. Green A. R. Pharmacological approaches to acute ischaemic stroke: reperfusion certainly, neuroprotection possibly / A. R. Green // Br. J. Pharmacol. -2008. - Vol. 153. P. 325-338.

5. Молекулярные механизмы формирования ише-

мической толерантности головного мозга: ч. 1 /Е. В. Шляхто, Е. Р. Баранцевич, Н. С. Щербак, М. М. Галагудза // Vestnik RAMN. - 2012. - T. 6. - C. 42-50.

6. 'Ischemic tolerance' phenomenon found in the brain / K. Kitagawa, M. Matsumoto, M. Tagaya [et al.] // Brain Res. - 1990. - Vol. 528 (1). - P. 21-24.

7. Hyperthermia induced neuronal protection against ischemic injury in gerbils / Kitagawa K., Matsumoto M., Tagaya M. [et al.] // J. Cereb. Blood Flow Metab. - 1991. Vol. 11 (3). - P. 449-452.

8. Murry C. E. Preconditioning with ischemia: a delay of lethal cell injury in ischemic myocardium / C. E. Murry, R. B. Jennings, K. A. Reimer // Circulation. - 1986. Vol. 74 (5). - P. 1124-1136.

9. Ma D. Xe-preconditioning reduces brain damage from neonatal asphyxia in rats / D. Ma // Cereb. Blood Flow. Metab. - 2006. - Vol. 26. - P. 199-208.

\title{
REFERENCES
}

1. Donnan, Y.A., Fisher, M., Macleod, M., \& Davis, S.M. (2008). Stroke. Lancet, 371, 1612-1623.

2. Sandercock, P., Berge, E., Dennis, M., Forbes, J., Hand, P., Kwan, J., ... \& Wardlaw, J. (2002). A systematic review of the effectiveness, coss-effectiveness and barriers to implementation of thrombolytic and neuroprotective therapy for acute ischaemic stroke in the NHS. Health Technol. Assess., 6 (26), 1-112.

3. Hashiguchi, A., Yano, S., Morioka, M., Hamada, J., Ushio, Yu., Takeuchi, Yu., \& Fukunaga, K. (2004). Up-regulation of endothelial nitric oxide synthase via phosphatidylinositol 3-kinase pathway contributes to ischemic tolerance in the CAl subfield of gerbil hippocampus. J. Ceber. Blood Flow Metab., 24 (3), 271-279.

4. Green, A.R. (2008). Pharmacological approaches to acute ischaemic stroke: reperfusion certainly, neuroprotection possibly. Br. J. Pharmacol., 153, 325-338.

5. Shlyakhto, E.V., Barantsevich, E.R., Shcherbak, N.S., \& Galagudza, M.M. (2012). Molekulyarnyye mekhanizmy

formirovaniya ishemicheskoy tolerantnosti golovnogo mozga. Ch. I. [Molecular mechanisms of formation of ischemic tolerance of the brain. Part 1]. Vestnik RAMN - Bulletin of RAMS, 6, 42-50 [in Russian].

6. Kitagawa, K., Matsumoto, M., Tagaya, M., Hata, R., Ueda, H., Niinobe, M., ... \& Mikoshiba, K. (1990). Ischemic tolerance phenomenon found in the brain. Brain Res., 528 (1), 21-24.

7. Kitagawa, K., Matsumoto, M., Tagaya, M., Kuwabara, K., Hata, R., Handa, N., ... \& Kamada, T. (1991). Hyperthermia induced neuronal protection against ischemic injury in gerbils. J. Cereb. Blood Flow Metab., 11 (3), 449-452.

8. Murry, C.E., Jennings, R.B., \& Reimer, K.A. (1986). Preconditioning with ischemia: a delay of lethal cell injury in ischemic myocardium. Circulation, 74 (5), 1124-1136.

9. Ma, D. (2006). Xe-preconditioning reduces brain damage from neonatal asphyxia in rats. Cereb. Blood Flow. Metab., 26, 199-208.

\section{ВИКОРИСТАННЯ ЗАХИСНИХ НЕЙРОФІЗІОЛОГІЧНИХ РЕАКЦІЙ ГОЛОВНОГО МОЗКУ ПРИ ФОРМУВАННІ ПРЕВЕНТИВНОЇ ІШЕМІЧНОЇ ТОЛЕРАНТНОСТІ» (ПРЕ- І ПОСТКОНДИЦІОНУВАННЯ) З МЕТОЮ ЛІКУВАННЯ ТА РЕАБІЛІТАЦІЇ ХВОРИХ З ПОСТІНСУЛЬТНИМИ ПСИХОПАТОЛОГІЧНИМИ РОЗЛАДАМИ}

\author{
ОК. В. Шевченко-Бітенський, В. С. Бітенський \\ ДУ «Український науково-дослідний інститут медичної реабілітації та курортології мОз України», \\ Odeca
}

РЕЗЮМЕ. За даними ВООЗ, від інсульту щорічно страждають більше 1 млн чоловік. Найчастіше трапляються ішемічні інсульти (87 \%), рідше - геморагічні (10 \%) або інсульти з крововиливами в субарахноїдальний простір (3\%).

Феномен «ішемічної толерантності» був введений K. Kitagawa в 1990 р. при описі захисного ефекту малих доз церебральних гіпертермій $\left(+35^{\circ} \mathrm{C}\right)$ від дії значно більш виражених подразників. Уперше подібний ефект був передбачений С. П. Боткіним (1867), застосований при гіпоксії міокарда С. M. Murry et al. в 1986 р.; він отримав назву «пре- і посткондиціонування». 
Огляди літератури, оригінальні дослідження, погляд на проблему, ювілеї

Мета - дослідити терапевтичну ефективність застосування так званої «ішемічної толерантності» у 48 хворих з різною психопатологічною симптоматикою, що виникає після перенесеного інсульту.

Матеріал і методи. Було проведено дослідження 48 хворих чоловіків з постінсультними психічними розладами у вигляді різної психопатологічної симптоматики.

Висновки. Застосування слабкої краніоцеребральної гіпо- і гіпертермії $\left(+35^{\circ} \mathrm{C}-37,5^{\circ} \mathrm{C}\right)$ створювало в тканині мозку ефект «ішемічної толерантності» i, разом з інгаляцією ксенону і введенням нейропротекторів церебролізину (10,0 мг) і вальпроату (400-800 мг), привело до практичного зникнення постінсультної психопатологічної симптоматики.

КЛючОВІ словА: постінсультна психопатологічна симптоматика; «ішемічна толерантність»; пре- і посткондиціонування; гіпо- і гіпертермія.

\section{APPLICATION OF NEUROPHYSIOLOGICAL BRAIN REACTION WHEN FORMING PREVENTIVE "ISCHEMIC TOLERANCE" (PRE- AND POST-CONDITIONING) FOR THE TREATMENT AND REHABILITATION OF PATIENTS WITH POSTSTROKE PSYCHOPATHOLOGICAL DISORDERS}

○K. V. Shevchenko-Bitenskyi, V. S. Bitenskyy

Ukrainian Research Institute of Medical Rehabilitation and Balneology of the Ministry of Health of Ukraine

SUMMARY. According to the WHO, more than 1 million people suffer from stroke annually. Most often, there are ischemic strokes (87 \%), rarely - hemorrhagic (10\%) or strokes from the circulation in subarachnoid space (3\%). The phenomenon of "ischemic tolerance" was introduced by K. Kitagawa in 1990 when describing the protective effect of small doses of cerebral hyperthermia $\left(+35^{\circ} \mathrm{C}\right)$ from the action of significantly more pronounced stimuli. For the first time such an effect was foreseen by S. P. Botkin (1867), applied at hypoxia of the myocardium S. M. Marri et al. in 1986; he was called "pre-and post-conditioning".

The aim - to investigate the therapeutic efficacy of the use of so-called "ischemic tolerance" in 48 patients with different psychopathological symptoms that occurs after a stroke.

Material and Methods. A study was conducted on 48 male patients with post-stroke psychiatric disorders in the form of various psychopathological symptoms.

Conclusions. The use of weak craniocerebral hypo and hyperthermia $\left(+35^{\circ} \mathrm{C}-37.5^{\circ} \mathrm{C}\right)$ created the effect of "ischemic tolerance" in the brain tissue and, along with inhalation of xenon and the introduction of neuroprotectors, cerebrolysin $(10.0 \mathrm{mg})$ and valproate $(400-800 \mathrm{mg})$, led to the practical disappearance of post-stroke psychopathological symptomatology.

KEY WORDS: postapoplectic psychopathological symptomatology; "ischemic tolerance"; pre- and post-conditioning; hypo- and hyperthermia.

Отримано 14.10 .2018 